\title{
STRATEGI KOMUNIKASI PENYEBARAN PESAN PERUBAHAN PADA PT. PERTANI (PERSERO)
}

\author{
Elda Clara Sophia ${ }^{1)}$, Lilyana Aprianty ${ }^{2)}$ \\ 1) The London School Of Public Relations Jakarta, email: tariganelda@gmail.com \\ ${ }^{2)}$ The London School Of Public Relations Jakarta, email: tariganelda@gmail.com
}

\begin{abstract}
Organizational culture is a belief, custom, value which exist in an organization in order to differ one organization and the other. Affairs in organizational culture unwittingly manage attitudes and behaviors of the organizational doers that its practice affects to the work environments. This research discusses about the practice of organizational culture values that are applied by PT Pertani (Persero) as one of Indonesian State Owned Enterprises after there were changes in Board of Directors. This research aims to find out the organizational change and the distribution of order changes along with the practice of organizational culture values in PT Pertani (Persero). Researcher uses the theory of organizational communication which focuses on organizational change and organizational culture. This is a qualitative descriptive research using the method of in-depth interview and observation. The result of this research is planned organizational changes found in PT Pertani (Persero) with the distribution of change process through tell and sell method in board meeting once a week, identify and reply by involving employees to create the concept of change for company development, and withold and uphold which is electing important information done by management to be distributed to all employees. After committing organizational changes, the practice of organizational culture values in PT Pertani (Persero) is performed based on Board of Directors' instructions which consist of enforcement of new regulations and a more disciplined and assertive way of working as well as advancing employees' rights in a form of income increase.
\end{abstract}

Keywords: Organizational Culture, Organizational Change, State-Owned Corporation

\section{PENDAHULUAN}

Keberadaan pemerintah dalam mensejahterakan masyarakat sangat bergantung pada sumber daya manusia. Untuk mencapai tujuan tersebut, pemerintah yang berperan sebagai organisasi harus memilih sumber daya masyarakat yang berkualitas. Pemilihan sumber daya manusia ini dianggap sangat penting karena berfungsi sebagai penggerak yang dapat mempengaruhi keberhasilan pencapaian tujuan organisasi yang efektif dan efisien (Tobari, 2015, p.1).

Sumber daya manusia atau pelaku organisasi akan memberikan ide-ide dan pemikiran terbaiknya yang membuat organisasi tersebut memiliki warna atau ciri khas sendiri dan menjadikan organisasi tersebut berbeda dengan organisasi lain. Pemimpin sebuah organisasi merupakan orang-orang yang tanpa disadari membentuk warna-warna dalam organisasi itu sendiri. Warna-warna tersebut sebenarnya adalah kultur atau budaya organisasi yang secara perlahan akan menjadi jiwa organisasi (Moeljono dan Sudjatmiko, 2007, p.43).

Budaya organisasi yang terinternalisasi secara optimal pada seluruh karyawan sebuah organisasi menjadi faktor penentu keseragaman sikap serta kesatuan pandangan dan perilaku. Terdapat empat warna budaya organisasi yang dapat dijalankan pada sebuah organisasi yang meliputi budaya pasar, budaya kewirausahaan, budaya klan, dan budaya birokrasi. Sebelum memilih budaya organisasi yang cocok dengan 
organisasi tersebut, pemimpin harus melakukan penelitian terhadap keadaan organisasi terlebih dahulu (Harismanto, 2017, 23 Januari). Pada PT. Pertani (Persero) warna budaya organisasi yang ada merupakan budaya birokrasi yang mengutamakan hirarki koordinasi, SOP, dan efisiensi jangka panjang yang kemudian diikuti oleh budaya pasar sebagai pengukur pencapaian target berdasarkan aspek keuangan (B. Irawan, wawancara pra-riset, 15 Maret 2017).

Pengembangan organisasi bergantung pada analisis dan identifikasi faktor-faktor yang menyimpulkan efektivitas sebuah organisasi (Shahzad, 2012, p.976). Organisasi mendapatkan komitmen karyawan, yang akan mengarah pada pengingkatan produktivitas. Hal ini merupakan tanggung jawab manajemen untuk memperkenalkan budaya organisasi kepada karyawan, agar dapat membantu karyawan untuk memahami sistem organisasi yang ada di dalamnya. Manajemen harus berusaha untuk selalu mempelajari apa saja yang terjadi dalam lingkungan kerja. Dengan pemahaman tentang budaya organisasi yang tepat, akan mengarah ke peningkatan kinerja karyawan. Kinerja karyawan dipandang sebagai tulang punggung sebuah organisasi. Sehingga organisasi ingin mendapatkan loyalitas yang tinggi dari karyawan (Shahzad, 2012, p.976).

Tercatat pada tahun 2017 BUMN Perum Perhutani mengalami peningkatan laba sebesar 138 persen dibandingkan dengan tahun sebelumnya. Hal ini disebabkan adanya transformasi bisnis untuk mengembalikan kestabilan perusahaan. Upaya transformasi ini mempelajari lebih dalam mengenai struktur organisasi, operasional, keuangan dan budaya organisasi yang berlaku di organisasi tersebut. Transformasi ini berfokus pada empat aspek utama yaitu organisasi, operasional, masyarakat berbudaya, dan keuangan (Praditya, 2017, 24 Mei).

PT. Pertani (Persero) merupakan pionir Badan Usaha Milik Negara yang berfokus pada sektor pertanian. Pada tahun 2016, terjadi restrukturisasi organisasi yang ditandai dengan pergantian Direksi. Pergantian ini memunculkan perubahan pada organisasi. Salah satunya adalah perubahan pada SOP (Standard Operating Procedure) dan optimalisasi penerapan nilai budaya perusahaan (B. Irawan, wawancara prariset, 15 Maret 2017).

Fenomena yang terjadi adalah setelah pergantian Direktur Utama, Pertani memiliki sedikit pemberitaan negatif dan lebih banyak pemberitaan positif. Perubahan ini tidak lepas dari penerapan nilai budaya organisasi yang terus ditingkatkan setiap harinya. Dengan Dewan Direksi sebelumnya, Pertani seringkali dikabarkan akan bangkrut dan telah mengabaikan hak-hak pegawainya. Pemberitaan Tribunnews (Sulistyawan, 24 Agustus 2015) mengatakan sekitar 1.125 pegawai PT. Pertani (Persero) tidak mendapat hak yang berupa gaji dan tunjangan selama hampir dua tahun. Masalah ketenagakerjaan ini dibahas serius oleh Kementerian Pertanian dan Kementerian BUMN.

Tetapi setelah memiliki pemimpin yang baru, citra PT. Pertani di pihak internal maupun eksternal mengalami perubahan dan semakin menunjukan penerapan nilai budaya organisasi PT. Pertani (Persero) (B. Irawan, wawancara pra-riset, 15 Maret 2017).

Jajaran direksi PT. Pertani (Persero) yang lama memiliki hutang yang jumlahnya cukup besar 
dan harus segera diselesaikan setelah adanya pergantian direksi. Hal ini merupakan tugas yang cukup berat bagi direksi baru dan seluruh karyawan PT. Pertani (Persero), tetapi seiring berjalannya kempemimpinan direksi baru PT. Pertani (Persero) mulai bangkit dari keterpurukan dan berusaha membenahi masalah-masalah sebelumnya. Kebangkitan PT. Pertani (Persero) ini tidak lepas dari budaya organisasi yang dijalankan dalam perusahaan tersebut (B. Irawan, wawancara pra-riset, 15 Maret 2017).

Beberapa bukti bahwa PT. Pertani (Persero) sedang berusaha untuk bangkit adalah pada awal kepemimpinan direksi baru, Perum BULOG mempercayai PT. Pertani (Persero) untuk kerja sama dalam pengolahan gabah dan beras di dalam negeri (Agustina, 2016, 30 Desember). Dilanjutkan dengan Kementerian Pertanian yang melibatkan PT. Pertani (Persero) dalam pengembangan benih komoditas pangan seperti padi, jagung, kedelai, dan tebu pada awal tahun 2017 (Julianto, 8 Februari 2017).

Dari penjelasan di atas, maka peneliti tertarik untuk meneliti tentang "Strategi Komunikasi Penyebaran Pesan Perubahan Pada PT. Pertani (Persero)".

\section{METODOLOGI PENELITIAN}

Metodologi penelitian yang digunakan peneliti adalah metodologi penelitian kualitatif dengan pendekatan deskriptif. Metodologi penelitian kualitatif merupakan penelitian yang memiliki beberapa tahapan sebelum hasil-hasil penelitian ini memberikan sumbangan terhadap ilmu pengetahuan. Pada penelitian ini, peneliti dituntut untuk berpikir secara induktif, yang artinya adalah peneliti mengumpulkan berbagai fakta dan fenomena-fenomena sosial dengan cara penelitian di lapangan yang kemudian melakukan analisis hingga teorisasi berdasarkan apa yang telah diamati tersebut (Bungin, 2008, p.6).

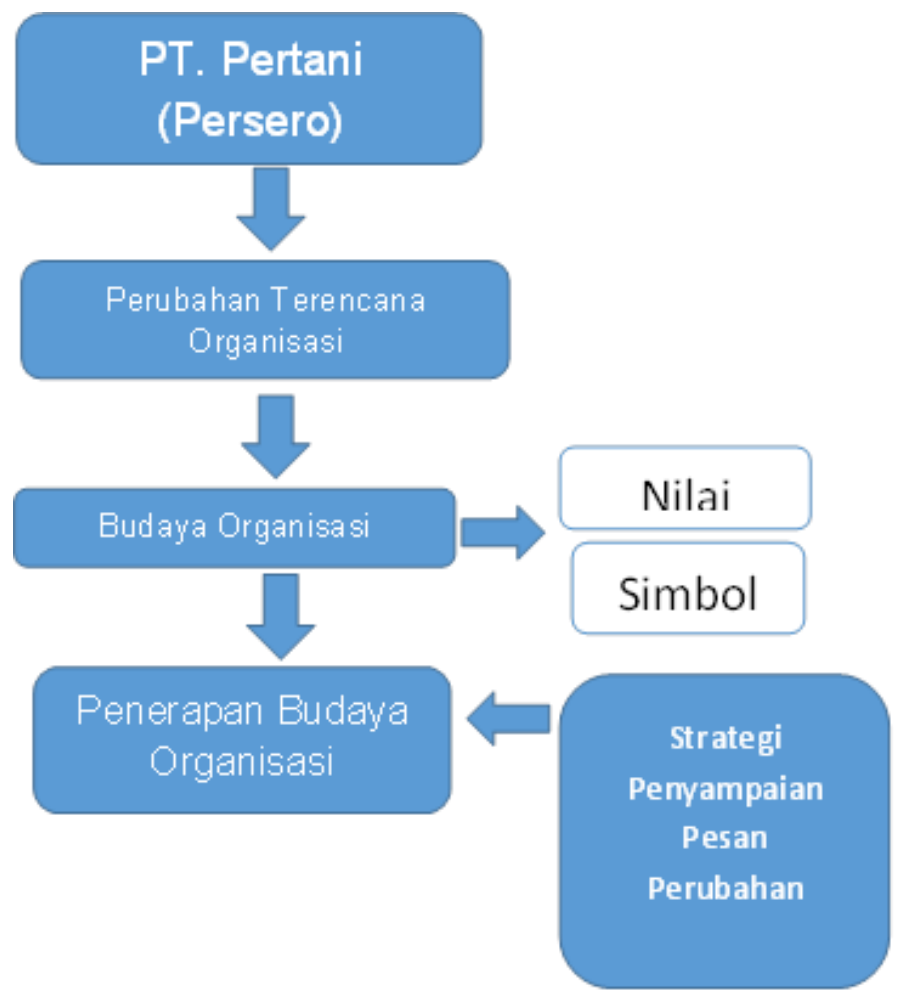

Gambar 1. Kerangka Penelitian,

Sumber; olahan data peneliti, 2016.

Menurut Moleong (2012, p.13), ada 2 cara yang dilakukan dalam pemilihan informan yaitu:

1. Melalui keterangan orang yang berwenang, baik secara informal (pemerintah) maupun secara informal (pemimpin masyarakat seperti tokoh masyarakat, pemimpin adat, dan lain- lain)

2. Melalui wawancara pendahuluan yang dilakukan oleh peneliti.

Narasumber yang memenuhi kriteria diatas meliputi narasumber internal. Karakteristik narasumber yang diperlukan dalam penelitian ini dibagi menjadi 2 kelompok, diantaranya: 
1. Pemegang Kuasa, merupakan para petinggi yang mempunyai wewenang dalam memberikan inovasi-inovasi, mengusulkan, dan menyetujui adanya perubahan pada budaya organisasi di PT. Pertani (Persero). Salah satu contoh pemegang kuasa adalah Direktur Utama dan jajaran Direktur lain atau Sekretaris Perusahaan yang biasa ditugaskan untuk memberikan ide-ide atau inovasi baru demi berkembangnya organisasi tersebut. Pada penelitian ini, Tatang Setiawan selaku Sekretaris Perusahaan akan dijadikan sebagai salah satu informan untuk memenuhi data yang dibutuhkan oleh peneliti.

2. Karyawan dan staff, orang-orang yang menjadi alat untuk mencerminkan perubahan budaya organisasi yang berpengaruh pada citra organisasi. Karyawan yang paling memahami iklim organisasi di PT. Pertani (Persero). Karyawan yang menempati bidang SDM (Sumber Daya Masyarakat) dan Hubungan Masyarakat termasuk dalam narasumber yang memenuhi kriteria pemilihan informan. Selain pemegang kekuasaan, Bambang Irawan sebagai Kepala Bagian Humas PT. Pertani (Persero) dan Aryo Prabowo selaku Kepala Sub Bagian Pengembangan SDM akan dijadikan sebagai narasumber yang mewakili karyawan dan staff PT. Pertani (Persero).

PT. Pertani (Persero) merupakan BUMN (Badan Usaha Milik Negara) yang dibentuk sejak tahun 1959 sebagai pionir yang berfokus pada sektor pertanian. Sejak awal didirikannya, PT. Pertani (Persero) mengalami beberapa perubahan. Tahun 1959 menjadi tahun didirikannya Badan Perusahaan
Produksi Bahan Makanan dan Pembukaan Tanah (BMPT) yang didasari oleh Undang-Undangan Darurat No. 1/1959 tanggal 14 Januari 1959. BMPT kemudian diubah menjadi Badan Pimpinan Umum Perusahaan Pertanian Negara (BPU Pertani) di tahun berikutnya. Tiga tahun berikutnya, BPU Pertani kembali berubah menjadi Perusahaan Pertanian Negara (PN Pertani). Setelah sepuluh tahun dengan status PN Pertani, Pertani mengalami peningkatan status menjadi perseroan terbatas dengan nama PT. Pertani (Persero) yang bertahan hingga saat ini.

Produk yang ditawarkan perusahaan ini meliputi pupuk, perbenihan, dan perberasan. Pupuk yang dihasilkan khususnya merupakan pupuk organik dan pupuk majemuk serta pembenah tanah. Sedangkan produk perbenihan terdiri dari benih padi, jagung, dan kedelai. Produk utama perberasan adalah beras kuaitas dan beras medium yang bahan bakunya diperoleh dari kerjasama dengan kelompok tani untuk menjamin mutunya.

Direksi PT. Pertani (Persero) saat ini dipimpin oleh Wahyu sebagai Direktur Utama yang diangkat berdasarkan Surat Keputusan Menteri BUMN Negara RI No. 275/MBU/2012/ tanggal 30 Juli 2012, No. SK-252-MBU11/2016 tanggal 7 November 2016, dan No. 274/MBU/12/2016 tanggal 28 Desember 2016.

PT. Pertani (Persero) memiliki jaringan pemasaran yang tersebar di seluruh wilayah Indonesia. Jaringan pemasaran terdiri dari tujuh kantor wilayah yang didukung oleh 30 cabang, 29 unit pemasaran, 30 unit produksi benih, enam unit produksi pupuk dan pestisida, serta 17 unit pergudangan agribisnis. PT. Petani (Persero) berenacana untuk memasang pengering padi modern di 120 titik sentra pangan yang tersebar di seluruh wilayah Indonesia. 


\section{HASIL DAN PEMBAHASAN}

Berdasarkan informasi yang diperoleh dari hasil wawancara mendalam, dapat dilihat bahwa adanya perbedaan pemahaman mengenai budaya organisasi perusahaan. Karyawan yang sudah bekerja selama 30 tahun menganggap kebudayaan yang ada pada PT. Pertani (Persero) hanya tentang bagaimana mengerjakan tugas pokok dengan baik dan benar. Sedangkan menurut karyawan lain yang telah bekerja selama 25 tahun dan karyawan yang masih terbilang baru dengan masa kerja enam tahun, budaya perusahaan pada PT. Pertani (Persero) meliputi lima poin tersebut diatas.

Peneliti menilai budaya organisasi pada PT. Pertani (Persero) tidak tersebar secara merata kepada seluruh karyawan karena kurangnya sosialisasi mengenai budaya organisasi perusahaan. Disamping budaya perusahaan, terdapat tatanan nilai yang terkandung dalam PT. Pertani (Persero).

Berdasarkan penjelasan dan informasi yang diperoleh, karyawan PT. Pertani (Persero) sudah menerapkan nilai-nilai atau prinsip-prinsip yang ada di organisasi. Hanya saja, tidak semua karyawan hafal prinsipprinsip tersebut secara terperinci. Secara umum, yang membedakan PT. Pertani (Persero) dengan organisasi lainnya adalah pada PT. Pertani (Persero) sangat menjunjung tinggi nilai Ketuhanan yang dapat dilihat dari kepercayaan karyawan yang menganggap bekerja merupakan bagian dari ibadah.
Berdasarkan asumsi teori budaya organisasi yang salah satunya mencakup nilai atau kebiasaan sehari-hari, dapat dilihat jawaban ketiga informan bahwa budaya organisasi yang diterapkan memiliki dampak yang cukup besar dalam meningkatkan efektivitas kerja karyawan.

Karakteristik budaya organisasi menyebutkan bahwa budaya merupakan sesuatu yang dapat dipelajari, dilaksanakan secara turun menurun, dan pada pelaksanaannya dikontrol oleh mekanisme dan proses sosial. Karakteristik ini sesuai dengan ciri-ciri budaya organisasi pada PT. Pertani (Persero), dilihat dari hasil wawancara dengan Tatang selaku Sekretaris Perusahaan yang sudah bekerja selama kurang lebih 30 tahun, mengatakan kebiasaan-kebiasaan perusahaan sudah dijalankan sejak dulu dan dapat diterima oleh para karyawan.

Dalam nilai yang terkandung pada budaya organisasi PT. Pertani (Persero) salah satunya menyebutkan adanya kerjasama. Menurut hasil observasi yang dilakukan peneliti, sering terjadi hubungan kerjasama antar karyawan PT. Pertani (Persero) dan salah satunya adalah kerjasama antar divisi. Dimana kerjasama dilakukan untuk memenuhi tugas yang telah diberikan oleh atasan. Contohnya pada bulan Maret 2017, Direksi memerintahkan bagian Humas untuk membenahi website perusahaan dan bekerjasama dengan bagian IT. Peneliti 
melihat adanya kerjasama dalam menyelesaikan tugas yang telah diberikan.

Dalam menggambarkan diri sebuah organisasi, dapat dilihat dari simbol yang ada dalam organisasi tersebut. Simbol dapat berbentuk kondisi fisik organisasi, logo, cara berpakaian, dan tingkah laku para karyawan sebagai pelaku organisasi. Untuk mengetahui lebih lanjut, akan dibahas mengenai cara berpakaian karyawan PT. Pertani melalui hasil wawancara mendalam dan pengamatan dari peneliti. Dilihat dari jawaban ketiga informan, dapat dikatakan seluruh karyawan sudah memiliki pemahaman yang sama mengenai aturan ini dan para karyawan menaati peraturan mengenai cara berpakaian yang berlaku di organisasi.

PT. Pertani (Persero) dimana perubahan dewan direksi merupakan keputusan berdasarkan peraturan yang telah ditetapkan dan diatur oleh Kementerian BUMN mengenai masa jabatan lima tahun Dewan Direksi yang menjabat pada BUMN.

Perubahan organisasi pada PT. Pertani juga disebabkan oleh faktor pendorong perubahan. Tunggal (2007, p.2) menuturkan terdapat enam faktor pendorong perubahan pada organisasi. Menurut hasil wawancara mendalam, PT. Pertani (Persero) mengalami adanya kegagalan organisasi yang ditandai dengan kurang berkembangnya jenis usaha yang dilakukan perusahaan saat era kepemimpinan Dewan Direksi yang lama. Selain itu, kedua informan mengatakan adanya faktor lain yaitu mengenai politik dan kepentingan pihak-pihak luar yang mempengaruhi perubahan organisasi dengan adanya pergantian Dewan Direksi yang bersamaan dengan berakhirnya masa jabatan satu periode Dewan Direksi lama. Didapati pula bahwa tujuan utama dilakukannya perubahan adalah untuk meningkatkan kinerja perusahaan dan mengembangkan jenis-jenis usaha dalam perusahaan.

Dalam tahapan refreezing dijelaskan juga mengenai kebutuhan akan perubahan yang dilakukan organisasi dan apa saja bentuk dukungan yang diberikan oleh manajemen tingkat atas kepada seluruh karyawan. pada tahap unfreezing ini, kebutuhan akan perubahan muncul saat perusahaan dirasa tidak mengalami kemajuan yang besar sehingga dilakukan perubahan dengan tujuan untuk meningkatkan kinerja perusahaan dan mengembangkan bisnis-bisnis yang sebelumnya tidak ada di perusahaan. Perubahan organisasi ini juga mendapatkan dukungan dari manajemen tingkat atas dalam bentuk motivasi-motivasi dan arahan yang seringkali diberikan oleh dewan direksi.

Memasuki tahapan moving, dimana pada tahap ini organisasi telah masuk pada fase perubahan yang melibatkan seluruh pelaku organisasi. Berikut ini merupakan jawaban dari Bambang Irawan saat ditanyakan intensitas komunikasi saat proses perubahan dan bagaimana cara untuk memperkuat tindakan, serta sejauh apa keterlibatan pelaku 
organisasi dalam tahap ini Dapat dilihat pada tahap moving atau tahap dimana perubahan telah terjadi, intensitas komunikasi yang terjadi dalam organisasi terjalin dengan baik dan cenderung meningkat setiap harinya. Hal ini ditunjukan dengan komunikasi antar divisi dalam organisasi yang membaik dan rasa kekeluargaan dalam organisasi yang semakin dirasakan oleh para karyawan. Dalam hal ini semua pelaku organisasi ikut terlibat dalam proses perubahan organisasi, semua karyawan ikut merasakan dan menjadi bagian dari budaya dan aturan-aturan baru yang diterapkan oleh dewan direksi baru. Tetapi, pergantian direksi bukan kewenangan dari seluruh karyawan melainkan kewenangan dari pemegang saham yaitu Kementerian BUMN. Untuk memperkuat tindakan dalam proses perubahan, dewan direksi yang baru memberikan arahan-arahan bagi karyawan mengenai aturan-aturan baru dan bagaimana cara bekerja yang lebih efektif guna meningkatkan kinerja dan performa perusahaan.

Tahap terakhir dalam perubahan terencana adalah refreezing, dimana pada tahapan ini terdapat dukungan yang dapat berupa pelatihan untuk karyawan, cara untuk menstabilisasikan organisasi setelah berlangsungnya perubahan, dan penghargaan yang diberikan kepada pelaku organisasi.

Tabel 1. Hasil Pembahasan

\begin{tabular}{|c|c|c|c|}
\hline Objek & Elemen & Evidensi & Temuan \\
\hline \multirow[t]{4}{*}{$\begin{array}{l}\text { Perubahan } \\
\text { Terencana } \\
\text { Organisasi }\end{array}$} & Unfreezing & Tujuan Perubahan & $\begin{array}{l}\text { Periode atau masa jabatan yang } \\
\text { sudah memasuki waktunya yaitu } \\
\text { lima tahun dan juga perubahan } \\
\text { dilakukan dalam rangka } \\
\text { meningkatkan kinerja dan } \\
\text { performa karyawan. }\end{array}$ \\
\hline & & $\begin{array}{l}\text { Dukungan } \\
\text { manajemen tingkat } \\
\text { atas. }\end{array}$ & $\begin{array}{l}\text { Motivasi untuk bekerja lebih giat } \\
\text { dan lebih efektif. }\end{array}$ \\
\hline & & $\begin{array}{l}\text { Kebutuhan akan } \\
\text { perubahan }\end{array}$ & $\begin{array}{l}\text { Manajemen yang lama dinilai } \\
\text { kurang produktif dan kurang } \\
\text { berkembang dalam memperluas } \\
\text { jenis-jenis usaha perusahaan. }\end{array}$ \\
\hline & Moving & Intensitas komunikasi & $\begin{array}{lrrr}\text { Berjalan dengan } & \text { baik antar } \\
\text { sesama karyawan dan sesama }\end{array}$ \\
\hline
\end{tabular}




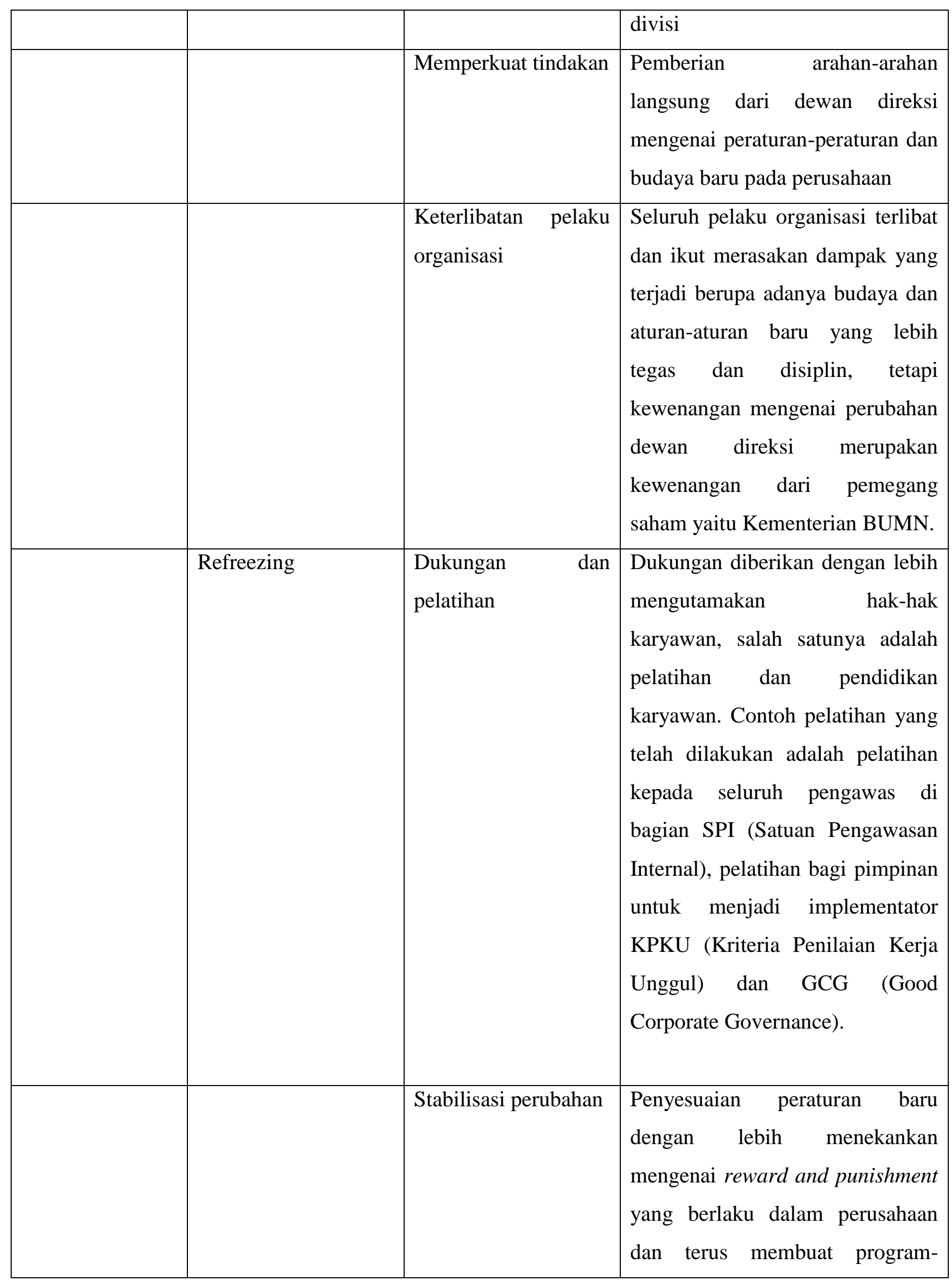




\begin{tabular}{|c|c|c|c|}
\hline & & & $\begin{array}{l}\text { program baru untuk memajukan } \\
\text { perusahaan. }\end{array}$ \\
\hline & & Penghargaan & $\begin{array}{l}\text { Dengan dituntunya cara kerja } \\
\text { yang lebih tegas dan disiplin, para } \\
\text { karyawan diberikan penghargaan } \\
\text { berupa adanya kenaikan } \\
\text { pendapatanatau gaji pokok secara } \\
\text { berkala untuk menyesuaikan } \\
\text { kinerja karyawan. }\end{array}$ \\
\hline $\begin{array}{l}\text { Budaya } \\
\text { Organisasi }\end{array}$ & Nilai & $\begin{array}{ll}\text { 1. Prinsip Dasar } \\
\text { Organisasi }\end{array}$ & $\begin{array}{l}\text { Berdasarkan analisis diatas } \\
\text { ditemukan bahwa prinsip-prinsip } \\
\text { dasar di dalam organisasi telah } \\
\text { diterapkan dan diketahui oleh } \\
\text { seluruh karyawan. Walaupun pada } \\
\text { penerapannya semua prinsip ini } \\
\text { telah dilaksanakan, tetapi tidak } \\
\text { semua poin dapat dihafal oleh } \\
\text { karyawan. Prinsip-prinsip atau } \\
\text { nilai-nilai dasar tersebut meliputi } \\
\text { integritas, profesionalisme, } \\
\text { kerjasama, komunikasi, adaptif, } \\
\text { dan sikap melayani. } \\
\text { Budaya perusahaan pada PT. } \\
\text { Peratni (Persero) meliputi bekerja } \\
\text { merupakan bagian daripada } \\
\text { ibadah, kedua berpikir positif, } \\
\text { bersikap jujur, dan bekerja secara } \\
\text { profesional. Ketiga bersikap } \\
\text { proaktif untuk meningkatkan } \\
\text { kinerja perusahaan, keempat } \\
\text { berusaha memperoleh hasil } \\
\text { pekerjaan yang lebih baik, serta } \\
\text { terakhir sinergi antara karyawan } \\
\text { dan masyarakat. }\end{array}$ \\
\hline
\end{tabular}




\begin{tabular}{|c|c|c|c|}
\hline & & 2. Efektivitas & $\begin{array}{l}\text { Budaya perusahaan yang telah } \\
\text { diterapkan pada PT. Pertani } \\
\text { (Persero) memiliki peran besar } \\
\text { untuk meningkatkan efektivitas } \\
\text { kerja karyawan. }\end{array}$ \\
\hline & & 3. Kerjasama tim & $\begin{array}{l}\text { Kerjasama tim yang terjadi pada } \\
\text { PT. Pertani (Persero) berjalan } \\
\text { dengan baik karena para } \\
\text { karyawan lancar berkomunikasi } \\
\text { antar sesama anggota tim. }\end{array}$ \\
\hline & 2. Simbol & 1. Kondisi Fisik & $\begin{array}{l}\text { Meliputi kondisi atau suasana } \\
\text { organisasi yang dapat dilihat dan } \\
\text { dirasakan langsung saat memasuki } \\
\text { organisasi yaitu sikap ramah para } \\
\text { karyawan terhadap tamu dan } \\
\text { suasana kekeluaragaan pada } \\
\text { lingkungan kerja. }\end{array}$ \\
\hline & & 2. Cara Berpakaian & $\begin{array}{l}\text { Senin menggunakan seragam } \\
\text { atasan putih dan bawahan biru, } \\
\text { Selasa - Kamis bebas rapi, dan } \\
\text { Jumat menggunakan batik. }\end{array}$ \\
\hline \multirow[t]{3}{*}{$\begin{array}{l}\text { Strategi } \\
\text { Komunikasi }\end{array}$} & $\begin{array}{l}\text { Teknik Penyampaian } \\
\text { Perubahan }\end{array}$ & 1. Spray and Pray & $\begin{array}{l}\text { Tidak terjadi di PT. Pertani karena } \\
\text { tidak semua informasi yang sama } \\
\text { akan dibagikan kepada seluruh } \\
\text { karyawan. }\end{array}$ \\
\hline & & 2. Tell and Sell & $\begin{array}{l}\text { Merupakan salah satu bagian dari } \\
\text { cara penyampaian perubahan. } \\
\text { Contohnya presentasi saat rapat } \\
\text { direksi seriap hari Senin pukul } 8 \\
\text { pagi. }\end{array}$ \\
\hline & & $\begin{array}{l}\text { 3. Underscore and } \\
\text { Explore }\end{array}$ & $\begin{array}{l}\text { Tidak terlalu cocok dengan PT. } \\
\text { Pertani (Persero) karena Direktur } \\
\text { Utama lebih tegas dan tidak }\end{array}$ \\
\hline
\end{tabular}




\begin{tabular}{|l|l|l|l|}
\hline & & $\begin{array}{l}\text { semua dapat } \\
\text { memberikan ide untuk kemajuan } \\
\text { perusahaan. }\end{array}$ \\
\hline & 4. Identify and Reply & $\begin{array}{l}\text { Melibatkan karyawan dalam } \\
\text { membuat agenda baru, kadang } \\
\text { terjadi tapi tidak semua karyawan } \\
\text { dapat terlibat. }\end{array}$ \\
\hline Uphold & Withold and & $\begin{array}{l}\text { Jika menyangkut dewan direksi } \\
\text { atau rahasia perusahaan, tidak } \\
\text { semua pegawai boleh mengetahui } \\
\text { informasi tersebut. Manajemen } \\
\text { akan memilih informasi apa saja } \\
\text { yang boleh dan tidak untuk } \\
\text { disebar. }\end{array}$ \\
\hline
\end{tabular}

Sumber : Data Olahan Peneliti, 2017

\section{PENUTUP}

Setelah dilakukan penelitian dengan metode wawancara terstruktur mendalam dan observasi, peneliti menemukan bahwa telah terjadi perubahan organisasi secara terencana dalam bentuk perubahan Dewan Direksi PT. Pertani (Persero). Dapat dilihat bahwa PT. Pertani (Persero) menggunakan teknik tell and sell, identify and reply, serta withold and uphold sebagai strategi komunikasi penyebaran pesan perubahan organisasi. Penggunaan teknik tell and sell terjadi setiap satu minggu pada saat rapat direksi saat manajemen memberikan penjelasan mengenai kelebihan-kelebihan dari perubahan yang disampaikan. Kedua adalah identify and reply penyebaran perubahan ini adalah ketika karyawan ikut berperan langsung dalam mengagendakan perubahan seperti pembuatan konsep dalam pengembangan bisnis yang dijalankan. Strategi terkahir yaitu withold and uphold yang dilakukan manajemen untuk memilih jenis informasi apa saja yang dianggap penting dan tidak penting untuk diketahui oleh karyawan, seperti tidak semua karyawan mengetahui alasan lain dibalik pergantian dewan direksi lama selain sudah memasuki satu periode masa jabatan direksi.

\section{Saran Akademis}

Peneliti memberikan saran agar penelitian ini dapat dijadikan sebagai referensi yang berguna untuk penelitian selanjutnya serta untuk menambah wawasan dan ilmu pengetahuan mengenai strategi komunikasi, budaya organisasi, dan perubahan organisasi. Peneliti menyarankan untuk melanjutkan 
penelitian di PT. Pertani (Prsero) secara lebih rinci lagi atau di perusahaan lainnya.

\section{Saran Praktis}

Peneliti menyarankan agar jajaran direksi lebih giat lagi dalam mensosialisasikan budaya organisasi kepada seluruh karyawan agar timbul lebih banyak lagi agen perubahan yang menjadi panutan untuk membangun organisasi lebih maju lagi. Tidak hanya itu, peneliti juga menyarankan untuk menambahkan teknik underscore and explore sebagai strategi dalam teknik penyebaran pesan pada internal PT. Pertani (Persero) agar manajemen lebih fokus pada isu-isu penting terkait perubahan pada organisasi.

\section{DAFTAR PUSTAKA}

Bulog Gandeng Pertani untuk Pengolahan

Gabah dan Beras. Detik. Diperoleh dari https://finance.detik.com/beritaekonomi-bisnis/d-3384053/buloggandeng-pertani-untuk-pengolahangabah-dan-beras

Bungin, M. B. (2008). Penelitian Kualitatif. Jakarta: Prenadamedia Group.

Harismanto. (2017, 23 Januari). Warna Budaya Organisasi Tentukan Capaian Kinerja. Tribun. Diperoleh dari http://pekanbaru.tribunnews.com/2017/ 01/23/warna-budaya-organisasitentukan-capaian-kinerja
Julianto, P. A. (2017, 8 Februari).

Kembangkan Benih Unggul, Kementan Libatkan BUMN Pertani. Kompas.

Diperoleh dari

http://ekonomi.kompas.com/read/2017/ 02/08/160000526/kembangkan.benih.u nggul.kementan.libatkan.bumn.pertani

Kriyantono, R. (2006). Teknik Praktis Riset

Komunikasi. Jakarta: Prenadamedia

Group.

Moeljono, D., \& Sudjatmiko, S. (2007). Corporate Culture: Challange to Excellence. Jakarta: Elex Media Komputindo.

Moleong, L. J. (2012). Meode Penelitian Kualitatif. Bandung:Remaja Rosdakarya.

Nugroho, R., dan Siahaan. R. (2005). BUMN Indonesia: Isu, Kebijakan, dan Strategi. Jakarta: Elex Media Komputindo.

Praditya, I.I. (2017, 24 Mei). Laba Perhutani Meningkat 138 Persen di Kuartal I 2017. Liputan6. Diperoleh dari http://www.liputan6.com.

Shahzad, F. (2012). Impact of Organizational Culture on Organizational Performance: An Overview. Journal of Contemporary Research in Business, 3(9), 975-985. Diperoleh dari http://www.journalarchieves 14.webs.com/975-985.pdf Sulistyawan, Y. (2015, 24 Agustus). Jangan Sampai 1.125 Karyawan PT Pertani 
Mati di Lumbung Padi. Tribunnews.

Diperoleh dari

http://www.tribunnews.com/nasional/2

015/08/24/jangan-sampai-1125-

karyawan-pt-pertani-mati-di-lumbung-

padi
Tobari. (2015). Membangun Budaya

Organisasi Pada Instansi Pemerintah.

Yogyakarta: Deepublisher.

Tunggal, A. W. (2007). Change Management.

Jakarta: Harvarindo. 